Jurnal Akuntansi dan Bisnis: Jurnal Program studi Akuntansi, 6 (1) Mei 2020.

ISSN 2443-3071 (Print) ISSN 2503-0337 (Online). DOI: 10.31289/jab.v6i1.3010

\author{
JURNAL AKUNTANSI DAN BISNIS \\ Jurnal Program Studi Akuntansi \\ Available online http://ojs.uma.ac.id/index.php/jurnalakundanbisnis
}

\title{
PENGARUH KEPEMILIKAN MANAJERIAL, PERTUMBUHAN PERUSAHAAN DAN FREE CASH FLOW TERHADAP KEBIJAKAN UTANG
}

\author{
Yuliana Rezki ${ }^{a}$, Hairul Anam ${ }^{*}$ \\ ${ }^{a}$ Fakultas Ekonomi, Universitas Balikpapan \\ Diterima Oktpber 2019; Disetujui Januari 2020; Dipublikasikan Mei 2020
}

\begin{abstract}
Abstrak
Penelitian ini bertujuan untuk menguji apakah Kepemilikan manajerial, Pertumbuhan Perusahaan dan Free Cash Flow berpengaruh terhadap Kebijakan Utang pada perusahaan Food and Beverage di Bursa Efek Indonesia. Populasi dalam penelitian ini adalah seluruh perusahaan Food and Beverage di Bursa Efek Indonesia. Pengambilan sampel tersebut menggunakan purposive sampling selama periode penelitian tahun 2013 sampai dengan 2017, dan diperoleh sampel sebanyak 4 perusahaan sampel dari 18 populasi perusahaan. Metode analisis yang digunakan dalam penelitian ini adalah regresi linear berganda. Hasil penelitian ini menunjukkan bahwa variabel Kepemilikan Manajerial berpengaruh terhadap Kebijakan Utang, sedangkan variabel Pertumbuhan Perusahaan dan Free Cash Flow tidak berpengaruh terhadap Kebijakan Utang pada perusahaan Food and Beverage di Bursa Efek Indonesia.
\end{abstract}

Kata Kunci: Kepemilikan Manajerial, Pertumbuhan Perusahaan, Free Cash Flow, Kebijakan Utang.

\begin{abstract}
This resaerch aims to examine whether Managerial Ownership, Company Growth and Free Cash Flow influence The Debt Policy of Food and Beverage companies on the Indonesian stock exchange. The sampling used side by side methods during the 2013 to 2017 research period, and a sample of 4 companies was obtained from 18 company populations. The analytical method used in this research is multiple linear regression.The results of this research indicate that Managerial Ownership variables have an effect on Debt Policy, while Company Growth and Free Cash Flow variables have no effect on Debt Policy in the Indonesian Stock Exchange Food and Beverage Companies.
\end{abstract}

Keyword: Managerial Ownership, Company Growth, Free Cash Flow, Debt Policy.

How To Cite: Yuliana Rezki, Hairul Anam (2020) Pengaruh Kepemilikan Manajerial, Pertumbuhan Perusahaan dan Free Cash Flow Terhadap Kebijakan Utang. Jurnal Akuntansi dan Bisnis: Jurnal Program Studi Akuntansi, 6 (1): 77 85

* email: hairul@uniba-bpn.ac.id

\section{PENDAHULUAN}

Perekonomian selalu mengalami perubahan serta persaingan yang cukup ketat dalam dunia usaha, sehingga persaingan tersebut khususnya pada perusahaan manufaktur membuat perusahaan harus lebih meningkatkan kinerja untuk mencapai tujuan yang diinginkan. Pada tahun 2013 sampai dengan tahun 2017 perusahaan Food and Beverage lebih sering mengalami laba daripada rugi, dan dapat dikatakan bahwa perusahaan Food and Beverage mengalami pertumbuhan kenaikan daripada mengalami penurunan. Namun demikian, pertumbuhan kenaikan tersebut tidak meningkat secara signifikan. Seorang manajer dalam mengambil keputusan cenderung untuk melindungi serta memenuhi kepentingan mereka terlebih dahuludaripada memenuhi kepentingan pemilik. Salah satu alternatif manager untuk memperoleh suatu dana adalah dengan 
meningkatkan utang. Akan tetapi kebijakan utang rentan terhadap konflik kepentingan antara pemegang saham, manajer dan kreditur yang sering disebut dengan konflik keagenan.

Bahri, (2017) mengemukakan bahwa untuk dapat bersaing dengan perusahaanperusahaan lain, maka perusahaan Food and Beverage dituntut untuk selalu melakukan performa dan lebih kreatif dalam hal memperoleh sumber pendanaan yang paling efektif. Keputusan dalam hal pendanaan merupakan hal yang paling penting bagi perusahaan, karena keputusan tersebut memiliki pengaruh terhadap risiko perusahaan dan keputusan pemberian kredit oleh kreditur. (Suryani \& Khalid, 2015) mengemukakan bahwa suatu perusahaan yang mengalami pertumbuhan yang tinggi berarti perusahaan tersebut berhasil meningkatkan nilai perusahaan untuk menghasilkan suatu keuntungan. Perusahaan yang memiliki pertumbuhan yang tinggi menunjukkan bahwa dengan sumber yang dimiliki perusahaan dapat menghasilkan pertumbuhan yang baik.

G.Agustian, (2014) mengemukakan bahwa dengan adanya kepemilikan manajerial akan mensejajarkan kepentingan antara manajemen dengan pemegang saham, sehingga manajer akan merasakan langsung manfaat dari keputusan yang diambil terutama keputusan mengenai utang. (Setiana \& Sibagariang, 2013) mengemukakan bahwa free cash flow merupakan kas perusahaan yang dapat didistribusikan kepada kreditur atau pemegang saham yang tidak diperlukan untuk modal kerja atau investasi pada aset. Berdasarkan latar belakang di atas, maka dalam penelitian ini akan dilihat Pengaruh Kepemilikan Manajerial, Pertumbuhan Perusahaan dan Free Cash Flow Terhadap Kebijakan Utang pada Perusahaan Food And Beverage di Bursa Efek Indonesia.

\section{METODE PENELITIAN}

\section{Kepemilikan Manajerial}

Yunandrianta, (2014) mengemukakan bahwa kepemilikan manajerial akan menanggung konsekuensi dari kebijakan yang diambil sehinng manajer akan lebih waspada untuk mengambil keputusan mengenai penggunaan utang. Karena kehatihatian manajer akan memberikan pengaruh terhadap kebijakan utang, dan dengan adanya kepemilikan manajerial akan mensejajarkan kepentingan antara manajemen dan pemegang saham. Selanjutnya, Murtiningtyas, (2012) mengemukakan rumusan kepemilikan manajerial sebagai berikut:

$$
\text { MOWN }=\frac{\text { Jumlah Kepemilikan Saham Manajerial }}{\text { Jumlah Saham yang Beredar }} \times 100 \%
$$

\section{Pertumbuhan Perusahaan}

Hardiningsih \& Oktaviani, (2012) mengemukakan bahwa suatu perusahaan yang mengalami pertumbuhan yang tinggi berarti perusahaan tersebut berhasil meningkatkan nilai perusahaan untuk menghasilkan keuntungan atau laba. Perusahaan dengan tingkat pertumbuhan yang tinggi akan lebih memaksimalkan penggunaan sumber daya yang dimiliki. Adapun Megawati \& Kurnia, (2015) merumuskan pertumbuhan perusahaan sebagai berikut:

$$
\text { Growth }=\frac{\text { Total Aset Akhir Tahun }- \text { Total Aset Awal Tahun }}{\text { Total Aset Awal Tahun }} \times 100 \%
$$




\section{Free Cash Flow}

Zurriah, (2018) mengemukkan bahwa free cash flow atau aliran kas bebas merupakan salah satu indikator untuk mengukur kemampuan perusahaan untuk mengembalikan keuntungan bagi para pemegang saham melalui pengurungan utang, peningkatan dividen atau pembelian saham kembali dan dengan hal tersebut nilai perusahaan juga akan ikut meningkat. Putra \& Fidiana, (2017) merumuskan free cash flow sebagai berikut:

$$
\text { FCF }=\text { CFO }- \text { CFI }
$$

\section{Kebijakan Utang}

Variabel dependen atau variabel terikat dalam penelitian ini yaitu Kebijakan Utang, di mana kebijakan utang perusahaan merupakan suatu keputusan yang diambil oleh manajemen untuk menentukan besarnya utang dalam sumber pendanaannya yang berguna untuk membiayai kegiatan operasional perusahaan. pembiayaan kegiatan operasinal dengan utang membuat perusahaan memiliki kewajiban untuk mengembalikan pinjaman dana, membayar beban bunga secara periodik, sehingga memaksa manajer untuk mengoptimalkan penggunaan dana yang ada. Yuniarti, (2013) merumuskan Debt To Equity Ratio (DER) sebagai berikut:

$$
\text { DER }=\frac{\text { Total Utang }}{\text { Total Modal }}
$$

\section{HASIL DAN PEMBAHASAN}

\section{Statistik Deskriptif}

Berdasarkan Tabel 1, diketahui bahwa jumlah data yang dimasukkan dalam pengujian penelitian ini sebanyak 20 data. Kepemilikan Manajerial memiliki nilai minimum sebesar 0,13, nilai maximum sebesar 33,84, rata-rata (mean) sebesar 6,4770, dengan standar deviasi sebesar 8,83664. Pertumbuhan perusahaan memiliki nilai minimum sebesar 0,22, nilai maximum sebesar 72,22, rata-rata (mean) sebesar 23,4795, dengan standar deviasi sebesar 18,38662. Free Cash Flow memiliki nilai minimum sebesar 13.728, nilai maximum sebesar 1.472.203, rata-rata (mean) sebesar 288.675,10, dengan standar deviasi sebesar 359.207,779. Data tersebut juga diolah dengan menggunakan tool Output SPSS versi 25

Berdasarkan Tabel 2 dari hasil perhitungan Kepemilikan Manajerial nilai tolerance sebesar 0,364 dan nilai VIF 2,746, Pertumbuhan Perusahaan nilai tolerance sebesar 0,965 dan nilai VIF sebesar 1,037, dan Free Cash Flow nilai tolerance sebesar 0,370 dan nilai VIF sebesar 2,706. Dapat disimpulkan bahwa tidak ada variabel independen yang memiliki nilai tolerance $<0,10$ (kurand dari), dan variabel independen memiliki nilai VIF $>10$. Sehingga dapat disimpulkan bahwa tidak ada multikolinieritas antar variabel dalam model regersi tersebut. 
Yuliana Rezki, Hairul Anam (2020) Pengaruh Kepemilikan Manajerial, Pertumbuhan Perusahaan dan Free Cash Flow Terhadap Kebijakan Utang...

Tabel 1 Hasil Uji Statistik Deskriptif

\begin{tabular}{cccccc}
\hline \multicolumn{5}{c}{ Descriptive Statistics } \\
\hline & $\mathrm{N}$ & Minimum & Maximum & Mean & Std. Deviation \\
\hline $\begin{array}{c}\text { Kepemilikan } \\
\text { Manajerial }\end{array}$ & 20 &, 13 & 33,84 & 6,4770 & 8,83664 \\
Pertumbuhan & 20 &, 22 & 72,22 & 23,4795 & 18,38662 \\
Perusahaan & & 13.728 & 1.472 .203 & $288.675,10$ & $359.207,779$ \\
Free Cash Flow & 20 &, 22 & 1,72 &, 9015 &, 44612 \\
Kebijakan Utang & 20 & & & & \\
Valid N (listwise) & 20 & & & & \\
\hline
\end{tabular}

\section{Uji Multikolinieritas}

\begin{tabular}{|c|c|c|c|c|c|c|c|}
\hline \multirow[t]{2}{*}{ Model } & \multicolumn{2}{|c|}{$\begin{array}{l}\text { Unstandardized } \\
\text { Coefficients }\end{array}$} & \multirow{2}{*}{$\begin{array}{c}\text { Standardized } \\
\text { Coefficients } \\
\text { Beta } \\
\end{array}$} & \multirow[t]{2}{*}{$\mathrm{t}$} & \multirow[t]{2}{*}{ Sig. } & \multicolumn{2}{|c|}{$\begin{array}{c}\text { Collinearity } \\
\text { Statistics }\end{array}$} \\
\hline & $\mathrm{B}$ & Std. Error & & & & Tolerance & VIF \\
\hline (Constant) & 1,100 & 0,141 & & 7,793 & 0,000 & & \\
\hline $\begin{array}{l}\text { Kepemilikan } \\
\text { Manajerial }\end{array}$ & $-0,041$ & 0,014 & $-0,805$ & $\begin{array}{c}- \\
2,949\end{array}$ & 0,009 & 0,364 & 2,746 \\
\hline $\begin{array}{l}\text { Pertumbuhan } \\
\text { Perusahaan }\end{array}$ & 0,001 & 0,004 & 0,060 & 0,357 & 0,726 & 0,965 & 1,037 \\
\hline Free Cash Flow & $1,067 \mathrm{E}-07$ & 0,000 & 0,086 & 0,317 & 0,755 & 0,370 & 2,706 \\
\hline
\end{tabular}

\section{Uji Autokorelasi}

Tabel 3. Hasil Uji Autokorelasi

\begin{tabular}{|c|c|c|c|c|c|}
\hline Model & $\mathrm{R}$ & R Square & Adjusted R Square & $\begin{array}{l}\text { Std. Error of } \\
\text { the Estimate }\end{array}$ & Durbin-Watson \\
\hline 1 &, $752^{\mathrm{a}}$ & 0,566 & 0,484 & 0,32033 & 2,230 \\
\hline \multicolumn{6}{|c|}{$\begin{array}{l}\text { a. Predictors: (Constant), Free Cash Flow, Pertumbuhan Perusahaan, Kepemilikan Manajerial } \\
\text { b. Dependent Variable: Kebijakan Utang }\end{array}$} \\
\hline
\end{tabular}

Berdasarkan tabel 3 diatas, niali Durbin Watson 2,230 dengan jumlah sampel 20n (n) dan jumlah variabel $3(\mathrm{k}=3)$, maka tabel Durbin Watson menunjukkan nilai $\mathrm{dl}=$ 0.9976 dan $d u=1.6763$. Dengan pengambilan keputusan $d u<d<4-d u, 1.6763<2.230$ $<2.3237$. Sehingga dapat diartikan bahwa $\mathrm{du}<\mathrm{d}<4-\mathrm{du}$, bahwa tidak terdapat gejala autokorelasi.

Berdasarkan tabel 4 berikut, maka regresi linear berganda dapat dirumuskan sebagai berikut:

$$
\mathrm{KU}=1,100-0,041 \mathrm{KM}+0,001 \mathrm{PP}-1,067 \mathrm{E}-07 \mathrm{FCF}+\mathrm{e}
$$

Bahwa sifat dari hubungan antara variabel terikat Kebijakan Utang (KU) dengan variabel bebas Kepemilikan Manajerial (KM), Pertumbuhan Perusahaan (PP) dan Free Cash Flow (FCF) dapat dilihat dari koefisiennya, apabila koefisien tersebut positif, maka perubahan variabel bebas searah dengan perubahan variabel terikat, sedangkan apabila koefisien tersebut negatif, maka perubahan variabel bebas dan variabel terikat berubah menjadi berlawanan. 
Persamaan regresi tersebut dapat disimpulkan bahwa Konstanta 1,100 yang artinya jika variabel-variabel independen tersebut nilainya 0 , maka variabel dependen atau variabel $\mathrm{Y}$ adalah 1,100. Koefisien regresi variabel $\mathrm{X}_{1}$ atau variabel Kepemilikan Manajerial adalah sebesar -0,041 berdasarkan arah koefisien tersebut menunjukkan bahwa peningkatan variabel Kepemilikan Manajerial akan menurunkan tingkat Kebijakan Utang perusahaan sebesar -0,041. Koefisien regresi variabel $\mathrm{X}_{2}$ atau variabel Pertumbuhan Perusahaan adalah sebesar 0,001 berdasarkan arah koefisien tersebut menunjukkan bahwa peningkatan variabel Pertumbuhan Perusahaan akan meningkatkan tingkat Kebijakan Utang perusahaan sebesar 0,001. Koefisien regresi variabel $\mathrm{X}_{3}$ atau variabel Free Cash Flow adalah sebesar -1,067E-07 berdasarkan arah koefisien tersebut menunjukkan bahwa peningkatan variabel Free Cash Flow akan menurunkan tingkat Kebijakan Utang perusahaan sebesar -1,067E-07.

\section{Regresi Linear Berganda}

Tabel 4. Hasil Uji Regresi Linear Berganda

\begin{tabular}{|c|c|c|c|c|c|c|c|}
\hline \multirow{2}{*}{ Model } & \multicolumn{2}{|c|}{$\begin{array}{l}\text { Unstandardized } \\
\text { Coefficients }\end{array}$} & \multirow{2}{*}{$\begin{array}{c}\text { Standardized } \\
\text { Coefficients } \\
\text { Beta }\end{array}$} & \multirow{2}{*}{$\mathrm{t}$} & \multirow{2}{*}{ Sig. } & \multicolumn{2}{|c|}{$\begin{array}{l}\text { Collinearity } \\
\text { Statistics }\end{array}$} \\
\hline & B & $\begin{array}{l}\text { Std. } \\
\text { Error }\end{array}$ & & & & Tolerance & VIF \\
\hline (Constant) & 1,100 & 0,141 & & 7,793 & 0,000 & & \\
\hline $\begin{array}{l}\text { Kepemilikan } \\
\text { Manajerial }\end{array}$ & $-0,041$ & 0,014 & $-0,805$ & $-2,949$ & 0,009 & 0,364 & 2,746 \\
\hline $\begin{array}{l}\text { Pertumbuhan } \\
\text { Perusahaan }\end{array}$ & 0,001 & 0,004 & 0,060 & 0,357 & 0,726 & 0,965 & 1,037 \\
\hline $\begin{array}{l}\text { Free Cash } \\
\text { Flow }\end{array}$ & 1,067E-07 & 0,000 & 0,086 & 0,317 & 0,755 & 0,370 & 2,706 \\
\hline
\end{tabular}

Uji Hipotesis Koefisien Determinasi $\left(\mathbf{R}^{2}\right)$

Tabel 5. Hasil Uji Koefisien Determinasi $\left(\mathrm{R}^{2}\right)$

\begin{tabular}{llllll} 
Model & $\mathrm{R}$ & R Square & $\begin{array}{l}\text { Adjusted } \\
\text { Square }\end{array}$ & $\begin{array}{l}\text { R } \\
\text { Estimate }\end{array}$ & Watson \\
\hline 1 &, $752^{\mathrm{a}}$ & 0,566 & 0,484 & 0,32033 & 2,230 \\
\hline $\begin{array}{l}\text { a. Predictors: (Constant), } \\
\text { Manajerial }\end{array}$ & Free Cash Flow, Pertumbuhan Perusahaan, Kepemilikan \\
\hline \multicolumn{4}{l}{ b. Dependent Variable: Kebijakan Utang } \\
\hline
\end{tabular}

Berdasarkan tabel 5 di atas, dapat disimpulkan bahwa $R$ Square disebut sebagai koefisien determinasi. Nilai Adjusted $R$ Square sebesar 0,484 atau 48,4\%, yang artinya variabel independen yaitu Kepemilikan Manajerial, Pertumbuhan Perusahaan dan Free Cash Flow dapat menjelaskan variabel Kebijakan Utang sebesar 48,4\%. Sedangkan sisanya 51,6\% (100\%-48,4\%) dijelaskan oleh variabel lain yang tidak diketahui dan tidak termasuk dalam analisis regresi ini.

Berdasarkan tabel 6 berikut, pada uji parsial menggunakan signifikansi 5\% atau 0,05. Maka didapat dijelaskan bahwa Kepemilikan Manajerial memiliki nilai t sebessar 2,949 dengan tingkat signifikansi 0,009. Dan nilai signifikansi tersebut berada di bawah $5 \%$ atau 0,05 sehingga dapat disimpulkan bahwa variabel Kepemilikan Manajerial berpengaruh terhadap Kebijakan Utang pada perusahaan Food and Beverage di Bursa 
Efek Indonesia. Pertumbuhan Perusahaan memiliki nilai t sebesar 0,357 dengan tingkat signifikansi 0,726. Dan nilai signifikansi tersebut berada di atas 5\% atau 0,05 sehingga dapat disimpulkan bahwa variabel Pertumbuhan Perusahaan tidak berpengaruh terhadap Kebijakan Utang pada perusahaan Food and Beverage di Bursa Efek Indonesia. Free Cash Flow memiliki nilai t sebesar 0,317 dengan tingkat signifikansi 0,755. Dan nilai signifikansi tersebut berada di atas 5\% atau 0,05 sehingga dapat disimpulkan bahwa variabel Free Cash Flow tidak berpengaruh terhadap Kebijakan Utang pada perusahaan Food and Beverage di Bursa Efek Indonesia.

Uji Parsial (Uji t)

Tabel 6. Hasil Uji Parsial (Uji t)

\begin{tabular}{cccccc}
\hline \multirow{2}{*}{ Model } & \multicolumn{2}{c}{$\begin{array}{c}\text { Unstandardized } \\
\text { Coefficients }\end{array}$} & $\begin{array}{c}\text { Standardized } \\
\text { Coefficients }\end{array}$ & $\mathrm{t}$ & Sig. \\
\cline { 2 - 4 } & $\mathrm{B}$ & Std. Error & Beta & & \\
\hline $\begin{array}{c}\text { (Constant) } \\
\text { Kepemilikan } \\
\text { Manajerial }\end{array}$ & 1,100 & 0,141 & & 7,793 & 0,000 \\
\hline $\begin{array}{c}\text { Pertumbuhan } \\
\text { Perusahaan }\end{array}$ & 0,001 & 0,004 & 0,060 & 0,357 & 0,726 \\
\hline $\begin{array}{c}\text { Free Cash } \\
\text { Flow }\end{array}$ & $1,067 \mathrm{E}-07$ & 0,000 & 0,086 & 0,317 & 0,755 \\
\hline Dependent Variable: Kebijakan Utang & & & & 0,009 \\
\hline
\end{tabular}

\section{Uji Simultan (Uji F)}

Tabel 7 Hasil Uji Simultan (Uji F) Anova

\begin{tabular}{lccccc}
\multicolumn{6}{c}{ Tabel 7 Hasil Uji Simultan (Uji F) Anova } \\
\hline $\begin{array}{c}\text { Sum of } \\
\text { Squares }\end{array}$ & df & $\begin{array}{c}\text { Mean } \\
\text { Square }\end{array}$ & F & Sig. \\
\hline Regression & 2,140 & 3 &, 713 & 6,950 &, $003^{\text {b }}$ \\
\hline Residual & 1,642 & 16 &, 103 & & \\
\hline Total & 3,781 & 19 & & & \\
\hline a. Dependent Variable: Kebijakan Utang & & \\
\hline b. Predictors: (Constant), Free Cash Flow, Pertumbuhan Perusahaan, \\
Kepemilikan Manajerial
\end{tabular}

Berdasarkan tabel7 di atas, pada uji simultan menggunakan nilai signifikansi 5\% atau 0,05. Sehingga dapat disimpulkan bahwa variabel Kepemilikan Manajerial, Pertumbuhan Perusahaan dan Free Cash Flow bersama-sama berpengaruh terhadap Kebijakan Utang pada Perusahaan Food and Beverage di Bursa Efek Indonesia.

Kepemilikan Manajerial berpengaruh terhadap Kebijakan Utang. Dengan menggunakan Uji parsial (uji t) menggunakan tingkat signifikansi $5 \%$ atau 0,05 di mana hasil ttabel -2,949 dengan tingkat signifikansi 0,009<0,05. Sehingga hasil penelitian ini menunjukkan bahwa Kepemilikan Manajerial berpengaruh terhadap Kebijakan Utang pada perusahaan Food and Beverage di Bursa Efek Indonesia. Artinya bahwa Kepemilikan Manajerial merupakan salah satu komponen penting dalam menentukan Kebijakan Utang, dan keberadaan manajer dalam perusahaan sangatlah penting untuk pengambilan keputusan yang nantinya akan berdampak pada perusahaan yang dikelolanya, dan keputusan tersebut dapat dilakukan dengan berbagai cara, salah satunya yaitu dengan Kebijakan Utang. Kebijakan tersebut dilakukan untuk menambah dana perusahaan, serta Kebijakan Utang dapat mengurangi konflik keagenan yang terjadi antara pemegang saham dan manajer. Hasil ini sejalan dengan penelitian terdahulu dari 
Gian Ginanjar Agustian dan Murdika Alamsyah Hasan (2014) yang menyatakan bahwa variabel Kepemilikan manajerial berpengaruh signifikan terhadap Kebijakan Utang.

Pertumbuhan Perusahaan tidak berpengaruh terhadap Kebijakan Utang.dengan menggunakan Uji parsial (uji t) menggunakan tingkat signifikansi 5\% atau 0,05 di mana hasil ttabel 0,357 dengan tingkat signifikansi 0,726 >0,05. Sehingga hasil penelitian ini menunjukkan bahwa Pertumbuhan Perusahaan tidak berpengaruh terhadap Kebijakan Utang pada perusahaa Food and Beverage di Bursa Efek Indonesia. Artinya setiap kenaikan pertumbuhan perusahaan tidak diikuti dengan kebijakan utang perusahaan, hal ini disebabkan karena perusahaan yang mengalami pertumbuhan yang tinggi menunjukkan bahwa dengan sumber daya yang dimiliki bisa menghasilkan pertumbuhan yang baik. Dan perusahaan dengan tingkat pertumbuhan yang tinggi akan lebih memaksimalkan penggunaan sumber daya yang dimiliki dan banyak menggunkan sumber pendanaan dari modal sendiri daripada utang. Hasil penelitian ini sejalan dengan hasil penelitian dari Beny (2013) dan Marhamah (2016) menyatakan bahwa Pertumbuhan Perusahaan tidak berpengaruh terhadap Kebijakan Utang.

Free Cash Flow tidak berpengaruh terhadap Kebijakan Utang. Dengan menggunakan Uji parsial (uji t) menggunakan tingkat signifikansi 5\% atau 0,05 dimana hasil ttabel 0,317 dengan tingkat signifikansi 0,755 >0,05. Sehingga hasil penelitian ini menunjukkan bahwa Free Cash Flow tidak berpengaruh terhadap Kebijakan Utang pada perusahaan Food and Beverage di Bursa Efek Indonesia. Artinya free cash flow yang dimiliki perusahaan memiliki angka yang cukup tinggi akan menurunkan kebijakan utang, karena semakin banyak atau tingginya free cash flow menunjukkan bahwa perusahaan semakin kaya sehingga tidak membutuhkan utang sehingga kebijakan utang semakin kecil. Ketika perusahaan mempunyai dana yang cukup tinggi maka perusahaan tidak menggunakan dana dari eksternal untuk mencukupi kebutuhan operasionalnya. Hasil penelitian ini sejalan dengan hasil penelitian dari Syaiful Bahri (2017) dan Rezki Zurriah (2018) menyatakan bahwa variabel Free Cash Flow tidak berpengaruh terhadap Kebijakan Utang.

\section{SIMPULAN}

Berdasarkan hasil penelitian tentang pengaruh variabel Kepemilikan Manajerial, Pertumbuhan Perusahaan dan Free Cash Flow terhadap Kebijakan Utang pada perusahaan Food and Beverage di Bursa Efek Indonesia tahun 2013 sampai dengan tahun 2017 menunjukkan bahwa variabel Kepemilikan Manajerial berpengaruh terhadap Kebijakan Utang, hal ini menunjukkan bahwa variabel Kepemilikan Manajerial merupakan salah satu komponen penting dalam menentukan Kebijakan Utang, dan keberadaan manajer sangatlah penting dalam menentukan suatu pengambilan keputusan perusahaan. Variabel Pertumbuhan Perusahaan tidak berpengaruh terhadap Kebijakan Utang. Hal ini dikarenakan setiap pertumbuhan perusahaan tidak diikuti dengan kebijakan uatang perusahaan, dan perusahaan yang mengalami pertumbuhan akan lebih memilih menggunakan sumber pendanaan dari modal sendiri daripada utang, sehingga perusahaan tersebut lebih memanfaatkan dana internalnya untuk membiayai kegiatan operasionalnya. Variabel Free Cash Flow tidak berpengaruh berpengaruh terhadap Kebijakan Utang. Artinya semakin meningkat free cash flow maka kebijakan utang semakin menurun, karena semakin tingginya free cash flow mennjukkan bahwa perusahaan semakin baik. 
Yuliana Rezki, Hairul Anam (2020) Pengaruh Kepemilikan Manajerial, Pertumbuhan Perusahaan dan Free Cash Flow Terhadap Kebijakan Utang...

\section{DAFTAR PUSTAKA}

Astuti, W. A., \& Nurlaelasari, N. (2013). Pengaruh Arus Kas Bebas dan Profitabilitas terhadap Kebijakan Utang. Trikonomika, 12(1), 40-48. ISSN 1411-514XX

Bahri, S. (2017). Pengaruh Kepemilikan Manajerial, Kebijakan Dividen, Profitabilitas, Ukuran Perusahaan Dan Arus Kas Bebas (Free Cash Flow) Terhadap Kebijakan Hutang. Jurnal Penelitian Teori Dan Terapan Akuntansi, 2(2). e-ISSN 2528-2581

Barus, S. R. dan A. C. (2018). Kebijakan Hutang Pada Perusahaan Sektor Utama Yang Terdaftar Di Bursa Efek Indonesia Periode 2013-2016. Jurnal Akuntansi, 8(2), 127-138. ISSN 2622-6421

Chariri, I. G. dan A. (2014). Teori Akuntansi (4th ed.). Semarang: Badan Penerbit Universitas Diponerogo.

Fidiana, Z. Y. P. dan. (2017). Pengaruh Arus Kas Bebas, Profitabilitas Dan Ukuran Perusahaan Terhadap Kebijakan Utang. 6(3), 1126-1147. ISSN 2460-0585

G. Agustian, W. Y. (2014). Pengaruh Kepemilikan Manajerial, Kepemilikan Institusional, Dan Kebijakan Dividen Terhadap Kebijakan Utang Perusahaan (studi pada perusahaan Property, Real Estate, \& Building Construction yang terdaftar di Bursa Efek Indonesia Tahun 2010 - 2013). 1(3), 203. ISSN 2355-9357

Ghozali, I. (2018). Aplikasi Analisis Multivariate dengan Program IBM SPSS 25 (9th ed.). Semarang: Badan Penerbit Universitas Diponegoro

Handayani, R., \& Indahningrum, R. P. (2009). Pengaruh Kepemilikan Manajerial, Kepemilikan Institusional, Dividen, Pertumbuhan Perusahaan, Free Cash Flow dan Profitabilitas Terhadap Kebijakan Hutang Perusahaan. Jurnal Bisnis Dan Akuntansi, 11(3), 189-207. ISSN 1410-9875 (p) e-ISSN 2656-9124

Jensen Michael, \& Meckling William H. (1976). Theory of the firm: managerial behavioragency and ownership structure. Journal of Financial Economics, 3, 305-360. https://doi.org/10.1016/0304405X(76)90026-X

Murtiningtyas, A. I. (2012). Kebijakan Deviden, Kepemilikan Manajerial, Kepemilikan Institusinal, Profitabilitas, Resiko Bisnis terhadap Kebijakan Hutang. Accounting Analysis Journal, 1(2), 1-6. https://doi.org/ISSN 2252-6765

Narita, M. R. (2012). Analisis Kebijakan Hutang. Accounting Analyasis Journal, 3(1), 361-369. https://doi.org/ISSN 2252-6765

Putri Khumairotul Ahyuni, N. R. dan Y. W. (2018). Pengaruh Free Cash Flow, Return On Asset (ROA) Dan Kepemilikan Institusional Terhadap Kebijakan Hutang (Studi Empiris pada Perusahaan Property dan Real Estate yang Listed di Bursa Efek Indonesia Tahun 2014-2016). 2(1), 56-65. e-ISSN 25986074 ISSN 2598-2885 (print)

Ross, S. A. (1977). The determination of financial structure The incentive signaling approach. Journal of Economics, 8(1), 23-40.

Setiana, E., \& Sibagariang, R. (2013). Pengaruh free cash flow dan kepemilikan manajerial terhadap kebijakan hutang pada perusahaan manufaktur yang terdapat di bursa efek indonesia. Jurnal Telaah Akuntansi, 15, 1. ISSN 1693-6760

Spence, M. (1973). Job Market Signaling. The Quarterly Journal of Economics, 87(3), 355-374. https://doi.org/10.1055/s-2004-820924

Sugiono. (2017). Metode Penelitian Kuantitatif, Kualitatif dan R\&D. Bandung: Alfabeta.

Suryani, A. D., \& Khafid, M. (2015). Pengaruh Free Cash Flow, Pertumbuhan Perusahaan, Kebijakan Dividen dan Ukuran Perusahaan Terhadap Kebijakan Hutang Pada Perusahaan Manufaktur Di Bursa Efek Indonesia Tahun 2013. Fakultas Ekonomi, Universitas Negeri Semarang, 4(1), 20-28. ISSN 19784878

Susanti. (2013). Analisis Variabel-Variabel yang Memengaruhi Kebijakan Utang Perusahaan. Jurnal Manajemen, 1, 798-914. ISSN 2549-192X

Trisnawati, I. (2016). Faktor-Faktor yang Mempengaruhi Kebijakan Hutang pada Perusahaan NonKeuangan yang Terdaftar di Bursa Efek Indonesia. Jurnal Ilmiah Permas:, 18(4), 33-42. ISSN 14109875

Yuli Fransiska, R. A. E. S. dan N. P. (2016). Pengaruh Kepemilikan Institusional , Kepemilikan Manajerial , dan Kebijakan Dividen terhadap Kebijakan Hutang Pada Perusahaan Manufaktur yang Terdaftar Di Bursa Efek Indonesia Tahun 2012-2014. 20, 1-15. Retrieved from https://media.neliti.com ISSN 2337-56XX

Yunandrianta, luluk muhimatul ifadah dan. (2014). Faktor-Faktor Yang Berpengaruh Terhadap Kebijakan Hutang Perusahaan (Studi Empiris pada Perusahaan Manufaktur yang terdaftar di Bursa Efek Indonesia Tahun 2012-2014) Luluk. 203. Jurnal Akuntansi dan Auditing, 14(1), 40-54. e-ISSN 25497650, ISSN 1412-6699 (p) 
Yuniarti, A. M. D. (2013). Pengaruh Kepemilikan Manajerial, Dividen, Profitabilitas dan Struktur Aset terhadap Kebijakan Hutang. Accounting Analysis Journal, 2(4), 447-454. https://doi.org/ISSN 22526765

Zurriah, R. (2018). Pengaruh Free Cash Flow dan Kepemilikan Manajerial terhadap Kebijakan Hutang (Studi Pada Perusahaan Yang Terdaftar di Jakarta Islamic Index). Jurnal Akuntansi Dan Bisnis : Jurnal Program Studi Akuntansi, 4(2), 31. https://doi.org/10.31289/jab.v4i2.1664 